Hydrol. Earth Syst. Sci., 13, 1597-1606, 2009

www.hydrol-earth-syst-sci.net/13/1597/2009/

(C) Author(s) 2009. This work is distributed under

the Creative Commons Attribution 3.0 License.

\title{
Landscape elements and river chemistry as affected by river regulation - a 3-D perspective
}

\author{
E. Smedberg ${ }^{1}$, C. Humborg ${ }^{1}$, M. Jakobsson ${ }^{2}$, and C.-M. Mörth ${ }^{2}$ \\ ${ }^{1}$ Baltic Nest Institute, Stockholm Resilience Centre, 10691 Stockholm, Sweden \\ ${ }^{2}$ Department of Geology and Geochemistry, Stockholm University, 10691 Stockholm, Sweden
}

Received: 17 September 2008 - Published in Hydrol. Earth Syst. Sci. Discuss.: 27 November 2008

Revised: 12 June 2009 - Accepted: 30 June 2009 - Published: 9 September 2009

\begin{abstract}
We tested the hypothesis whether individual land classes within a river catchment contribute equally to river loading with dissolved constituents or whether some land classes act as "hot spots" to river loading and if so, are these land classes especially affected by hydrological alterations. The amount of land covered by forests and wetlands and the average soil depth (throughout this paper soil refers to everything overlying bedrock i.e. regolith) of a river catchment explain $58-93 \%$ of the variability in total organic carbon (TOC) and dissolved silicate (DSi) concentrations for 22 river catchments in Northern Sweden. For the heavily regulated Luleälven, with 7 studied sub-catchments, only 3\% of the headwater areas have been inundated by reservoirs, some $10 \%$ of the soils and aggregated forest and wetland areas have been lost due to damming and further hydrological alteration such as bypassing entire sub-catchments by headrace tunnels. However, looking at individual forest classes, our estimates indicate that some $37 \%$ of the deciduous forests have been inundated by the four major reservoirs built in the Luleälven headwaters. These deciduous forest and wetlands formerly growing on top of alluvial deposits along the river corridors forming the riparian zone play a vital role in loading river water with dissolved constituents, especially DSi. A digital elevation model draped with land classes and soil depths which highlights that topography of various land classes acting as hot spots is critical in determining water residence time in soils and biogeochemical fluxes. Thus, headwater areas of the Luleälven appear to be most sensitive to hydrological alterations due to the thin soil cover (on average $2.7-4.5 \mathrm{~m}$ ) and only patchy appearance of forest and wetlands that were significantly perturbed. Hydrological alter-
\end{abstract}

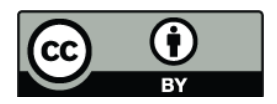

Correspondence to: E. Smedberg (erik@mbox.su.se) ations of these relatively small headwater areas significantly impacts downstream flux of dissolved constituents and their delivery to receiving water bodies.

\section{Introduction}

The number of dams world wide is constantly growing (Vörösmarty and Sahagian, 2000). Damming projects and other large-scale anthropogenic alterations in river catchments change the biogeochemical cycles and thus affect the nutrient fluxes from the catchments (Friedl and Wuest, 2002; Meybeck, 2002). This effect caused by damming was first observed after the building of the Aswan High Dam and was called the reservoir lakes effect (Van Bennekom and Salomons, 1979). The reduced transport of dissolved inorganic nitrogen (DIN), dissolved inorganic phosphorus (DIP) and dissolved silicate (DSi) to the Mediterranean Sea was explained by the uptake of these nutrients in the reservoir by phytoplankton blooms and especially diatom blooms that are efficient in sequestering biogenic elements in aquatic systems (Dugdale and Wilkerson, 1998; Ittekkot et al., 2000). Decreased fluxes of DSi in regulated rivers have been noted for many river systems (Turner and Rabalais, 1994; Humborg et al., 1997; Garnier et al., 1999). However, lower fluxes of dissolved constituents have been also observed in more oligotrophic (Garnier et al., 1999) and even ultraoligotrophic river systems (Brydsten, 1990), thus there must be fundamental processes involved other than diatom blooms to explain the lower fluxes of biogenic elements. One important factor is organic matter influencing silicate weathering (Millot et al., 2003) thus making vegetation, the ultimate source of total organic carbon (TOC) in these catchments, a vital land class component. Humborg et al. (2002) suggested

Published by Copernicus Publications on behalf of the European Geosciences Union. 


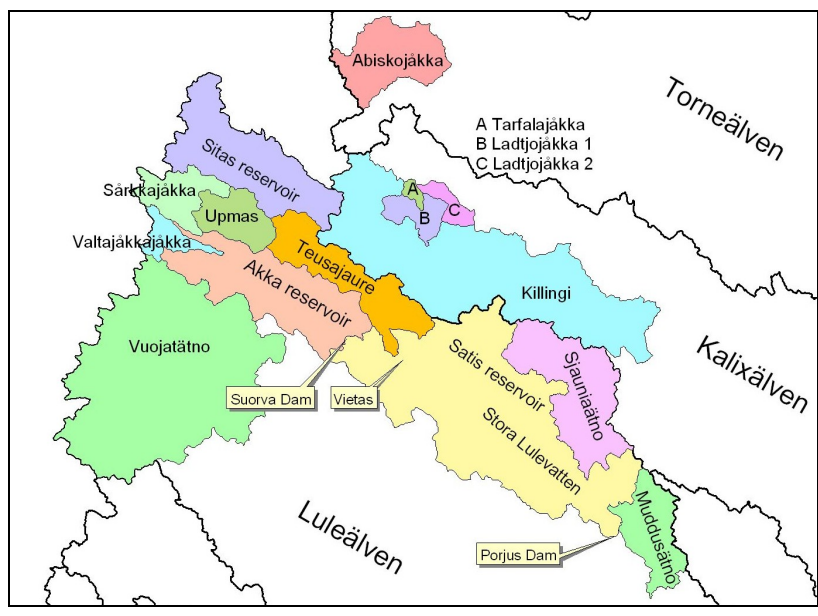

Fig. 1. The investigated sub-catchments in the rivers Torneälven, Kalixälven and Luleälven. The Suorva and Porjus dams are marked. The catchment of Sitas is routed through a tunnel into the Akkajaure reservoir, thus bypassing the Teusajaure catchment. Tunnels are also leading water from the reservoirs Akka and Satis to the hydroelectric power plant of Vietas. Stora Lulevatten is a run-of-river reservoir.

that altered weathering regimes caused by hydrological alterations that in turn lead to less contact of waters with vegetated soils could significantly contribute to the observed alteration in fluxes. Moreover, different vegetation types may affect weathering to varying degrees, i.e., biomass-normalized weathering fluxes are greater from deciduous forests (mainly birch) than from coniferous forests (Moulton et al., 2000).

In a comparison of two boreal rivers, the Luleälven (regulated) and the Kalixälven (unregulated), the unregulated river were found to have twice the concentration levels of discharge-weighted means of total organic carbon (TOC) and dissolved silica (DSi) (Humborg et al., 2002). Even the DSi yield of the heavily dammed River Luleälven $\left(768 \mathrm{~kg} \mathrm{~km}^{-2} \mathrm{yr}^{-1}\right)$ constituted only $58 \%$ of that found in the unregulated River Kalixälven $\left(1316 \mathrm{~kg} \mathrm{~km}^{-2} \mathrm{yr}^{-1}\right)$, despite the annual specific discharge of the River Luleälven $\left(698 \mathrm{~mm} \mathrm{yr}^{-1}\right.$ ) being $22 \%$ higher than that of the River Kalixälven $\left(571 \mathrm{~mm} \mathrm{yr}^{-1}\right)$. A recent model study in the Luleälven catchment (Sferratore et al., 2008) concluded that a combination of two factors, diatom blooms behind the dams, and loss of soils within the 4th and 5th order streams, have significantly contributed to the observed lower fluxes. In fact, only a few percent of the area of the catchments was affected through direct inundations (Carlsson and Sanner, 1994). Thus the question arises how a change in such a relatively small area can cause such a large reduction in DSi and TOC discharge weighted annual mean concentrations.

In this study we wanted to test the hypothesis whether individual land classes within a river catchment contribute equally to river loading with dissolved constituents and whether some land classes act as "hot spots" to river load-

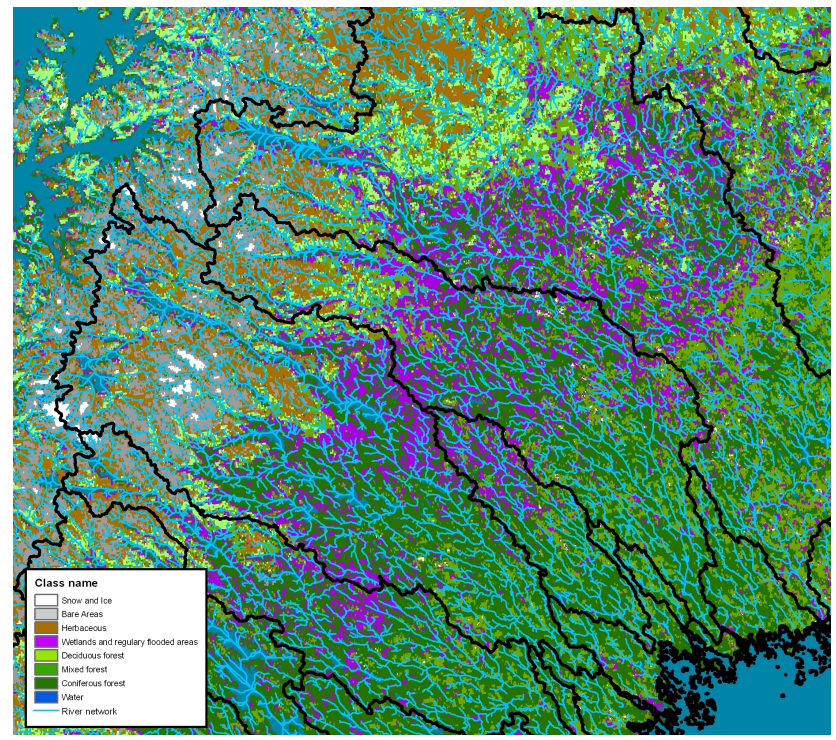

Fig. 2. Land class zonations in river catchments of Northern Sweden. The high altitude mountainous headwater area is dominated by herbaceous and bare areas. The next dominating land cover classes are deciduous forests and wetlands found at the hill slopes. The mixed and coniferous forests are dominating the lowland areas down to the coast.

ing and if so, are these land classes especially affected by hydrological alterations. This study aims to highlight such potential "hot spots" in catchments with regard to dissolved constituents, showing that alterations of a relatively small area can result in major changes in river chemistry if vital areas are affected. Estimates of the areas of land classes and the reduction in area of certain classes containing potential hot spots for river loading with DSi (Struyf and Conley, 2009), were derived from 2-dimensional GIS maps. Moreover, we developed a digital elevation model (DEM) for the area draped with land classes and soil depths which highlights that topography of various land classes is critical in determining water residence time in soils and biogeochemical fluxes (Laudon et al., 2007). Finally, we estimated the role of soil cover and soil depth for the river chemistry in these catchments and estimated the losses of soils due to river regulation. Thus, this study gives a 3-D perspective on how land class elements and river chemistry are related and how river regulation has changed these relationships.

\section{Methods}

\subsection{Study area}

The investigation was carried out in the northern part of Sweden, north of latitude $63^{\circ} 45^{\prime}$. The major catchments of the rivers Umeälven, Skellefteälven, Piteälven, Luleälven, Råneälven, Kalixälven and Torneälven were included in this 
Table 1. Hydrological status, area, altitude, average soil depth, percentage of coniferous forest, deciduous forest, mixed forest, wetland and herbaceous, annual specific discharge, runoff and discharge weighted annual mean concentration and yield of total organic carbon (TOC) and dissolved silica (DSi) in the investigated river catchments.

\begin{tabular}{|c|c|c|c|c|c|c|c|c|c|c|c|c|c|c|c|}
\hline Catchment & status & $\begin{array}{l}\text { Area } \\
\mathrm{km}^{2}\end{array}$ & m a.s.l. & $\begin{array}{r}\text { Average } \\
\text { soil } \\
\text { depth } \mathrm{m}\end{array}$ & $\begin{array}{r}\text { Coniferous } \\
\text { forest } \\
\%\end{array}$ & $\begin{array}{r}\text { Deciduous } \\
\text { forest } \\
\%\end{array}$ & $\begin{array}{r}\text { Mixed } \\
\text { forest } \\
\%\end{array}$ & Wetland & Herbaceous & $\begin{array}{r}\text { Annual } \\
\text { specific } \\
\text { discharge mm }\end{array}$ & $\begin{array}{r}\text { Runoff } \\
\mathrm{km}^{3}\end{array}$ & $\begin{array}{r}\text { TOC } \\
\mu \mathrm{mol} \mathrm{L}^{-1}\end{array}$ & $\begin{array}{r}\text { DSi } \\
\mu \mathrm{mol} \mathrm{L}^{-1}\end{array}$ & $\begin{array}{r}\text { TOC yield } \\
\mathrm{Kg} / \mathrm{km}^{-2} / \\
\mathrm{yr}^{-1}\end{array}$ & $\begin{array}{r}\mathrm{DSi} \text { yield } \\
\mathrm{Kg} / \mathrm{km}^{-2} / \\
\mathrm{yr}^{-1}\end{array}$ \\
\hline Torneälven $^{c}$ & Unregulated & 39865 & & 7.2 & 24.0 & 9.9 & 23.8 & 18.4 & 15.0 & 348.4 & 13.89 & 540 & 86.5 & 2258 & 844 \\
\hline Abiskojåkkaa & Pristine & 563 & 341 & 4.2 & 2.2 & 8.3 & 6.6 & 7.2 & 35.5 & & & 150 & 30.8 & & \\
\hline Kalixälven ${ }^{c}$ & Unregulated & 17982 & & 7.6 & 43.1 & 2.9 & 19.1 & 20.4 & 6.9 & 571.7 & 10.28 & 438 & 82.2 & 3005 & 1316 \\
\hline Tarfalajåkka & Pristine & 35 & 530 & 1.7 & 0.0 & 8.3 & 0.0 & 0.0 & 20.8 & 569.5 & 0.02 & 29 & 22.5 & 199 & 360 \\
\hline Ladtjojåkka 1 & Pristine & 203 & 513 & 3.4 & 6.1 & 9.0 & 4.0 & 0.4 & 33.2 & 592.1 & 0.12 & & 53.6 & & 887 \\
\hline Ladtjojåkka 2 & Pristine & 300 & 500 & 3.9 & 8.5 & 8.3 & 5.4 & 2.0 & 35.1 & 566.7 & 0.17 & & 66.2 & & 1050 \\
\hline Killingi & Pristine & 2330 & 460 & 5.9 & 4.5 & 11.4 & 19.7 & 12.3 & 34.9 & 540.8 & 1.26 & 179 & 76.8 & 1162 & 1163 \\
\hline Råneälven ${ }^{\mathrm{c}}$ & Unregulated & 4174 & & 8.1 & 60.4 & 0.1 & 17.1 & 18.8 & 0.0 & 352.2 & 1.47 & 579 & 97.2 & 2447 & 958 \\
\hline Luleälven $^{\mathrm{c}}$ & Regulated & 25060 & & 6.0 & 35.0 & 3.8 & 9.2 & 14.4 & 14.4 & 698.3 & 17.5 & 203 & 39.3 & 1701 & 768 \\
\hline Upmas & Pristine & 308 & 453 & 4.8 & 10.0 & 7.8 & 10.7 & 3.3 & 38.0 & 1006.4 & 0.31 & 88 & 17.0 & 1063 & 479 \\
\hline Sǻrkkajåkka & Pristine & 300 & 453 & 3.4 & 3.4 & 3.4 & 8.0 & 7.8 & 26.8 & 1200.0 & 0.36 & 47 & 9.7 & 677 & 326 \\
\hline Valtajåkka & Pristine & 149 & 453 & 5.1 & 6.9 & 9.3 & 8.8 & 15.7 & 26.5 & 469.0 & 0.07 & 82 & 30.6 & 462 & 403 \\
\hline Voujatätno & Pristine & 2844 & 453 & 3.5 & 3.7 & 3.4 & 5.4 & 3.4 & 34.9 & 1206.0 & 3.43 & 39 & 15.7 & 564 & 530 \\
\hline Sitas & Regulated & 978 & 614 & 2.7 & 5.0 & 0.4 & 3.1 & 2.2 & 30.3 & 1288.0 & 1.26 & 43 & 12.0 & 665 & 433 \\
\hline Akka res. & Regulated & 5625 & 453 & 3.5 & 5.1 & 3.5 & 5.3 & 4.6 & 32.1 & 864.0 & 4.86 & 71 & 13.2 & 736 & 319 \\
\hline Teusajaure & Bypassed & 650 & 499 & 4.5 & 9.9 & 5.6 & 6.9 & 3.3 & 36.2 & & & & & & \\
\hline Sjauniaätno & Pristine & 858 & 372 & 8.0 & 33.1 & 4.6 & 14.6 & 40.1 & 6.1 & 442.8 & 0.38 & 360 & 73.2 & 1913 & 908 \\
\hline Porjus & Regulated & 9883 & 372 & 4.7 & 13.4 & 4.5 & 7.8 & 12.4 & 26.1 & 828.7 & 8.19 & & 22.4 & & 520 \\
\hline Muddusätno ${ }^{\mathrm{b}}$ & Pristine & 450 & 382 & 8.2 & 41.3 & 0.2 & 1.8 & 55.6 & 0.0 & 422.2 & 0.19 & 470 & 78.4 & 2381 & 927 \\
\hline Piteälven ${ }^{\mathrm{c}}$ & Unregulated & 11206 & & 7.2 & 52.8 & 2.5 & 11.8 & 15.2 & 7.2 & 529.2 & 5.93 & 320 & 66.3 & 2032 & 982 \\
\hline Skellefteälven ${ }^{\mathrm{c}}$ & Regulated & 11652 & & 6.6 & 50.3 & 4.1 & 14.4 & 7.1 & 6.4 & 502.9 & 5.86 & 321 & 39.9 & 1937 & 562 \\
\hline Umeälven $^{\mathrm{c}}$ & Regulated & 26637 & & 7.2 & 51.1 & 7.4 & 17.5 & 6.7 & 6.5 & 571.4 & 15.22 & 325 & 46.8 & 2228 & 749 \\
\hline
\end{tabular}

River chemistry Humborg et al. (2002) and Humborg et al. (2004)

${ }^{a}$ Runoff and river chemistry data from monthly measurements by the SLU between 1982-2006

b Runoff and river chemistry data from monthly measurements monitored at the river mouths by the SLU between 1988-2000

${ }^{c}$ Runoff and river chemistry data from monthly measurements monitored at the river mouths by the SLU between 1970-2000

study. In addition, a number of sub-catchments in the headwater areas of rivers Luleälven, Kalixälven and Torneälven were investigated and special focus was directed to the drainage areas of Porjus, which encompasses the major part of the headwater area of the regulated River Luleälven (Fig. 1).

Climate in the northern part of Sweden is typically subarctic, with continuous frost from mid October to May (Alexandersson, 1991). Prevailing westerly winds deliver precipitation to the headwater areas in the range of 1000 to $2000 \mathrm{~mm} \mathrm{yr}^{-1}$ (Carlsson and Sanner, 1994). The annual specific discharge of the investigated river catchments spans from under $400 \mathrm{~mm}$ to over $1200 \mathrm{~mm}$ (Table 1). All the major rivers run from northwest to southeast. Population density in general is low. The small numbers of cities are all located on the coast with a few exceptions. Apart from the regulations of the rivers Umeälven, Skellefteälven and Luleälven, the area may be regarded as relatively undisturbed. A distinct altitudinal gradient in land classes can be seen, making this area ideal to study the function of individual land classes for river chemistry. Bare areas and herbaceous vegetation including alpine heath, dominate the land cover in the high altitude headwater area (Fig. 2). These land classes are followed by a band of deciduous forests (mainly birch, Betula ssp.), which also constitute the upper tree-line, and wetlands with regularly flooded areas (Fig. 2). Finally the coniferous and mixed forests cover the remaining area down to the coastline (Fig. 2).
A special focus was given to the headwaters of the River Luleälven catchment, since dams and headrace tunnels most heavily affect this area. Though this area occupies some $39 \%$ of the entire catchment area of the River Luleälven, it generates about $50 \%$ of the water discharge. Moreover, detailed river chemistry data have been compiled (Humborg et al., 2002, 2004) and these data can be compared with the adjacent headwater catchments of the rivers Kalixälven and Torneälven with similar hydrological and geomorphological settings.

Within the mountainous headwaters of the regulated River Luleälven four major reservoirs have been built (Fig. 1). From the Sitasjaure reservoir (614 $\mathrm{m}$ a.s.l.) the water is lead through a tunnel to the Ritsem hydroelectric power plant and then into the large Akka reservoir (453 m.a.s.1.), thus bypassing the valley of Teusajaure. The four undisturbed subcatchments of Vuojatätno, Valtajåkka, Sårkkajåkka and Upmas also drain into the Akka Reservoir. At the downstream end of the Akka reservoir the Suorva Dam is located. From there the water is lead in tunnels to the Vietas hydroelectric power plant that also receives water from the Satisjaure reservoir (457 $\mathrm{m}$ a.s.1.). Downstream of Vietas, the water passes a run-of-river impoundment, Stora Lulevatten, before reaching the Porjus Dam (372 m a.s.1.). 


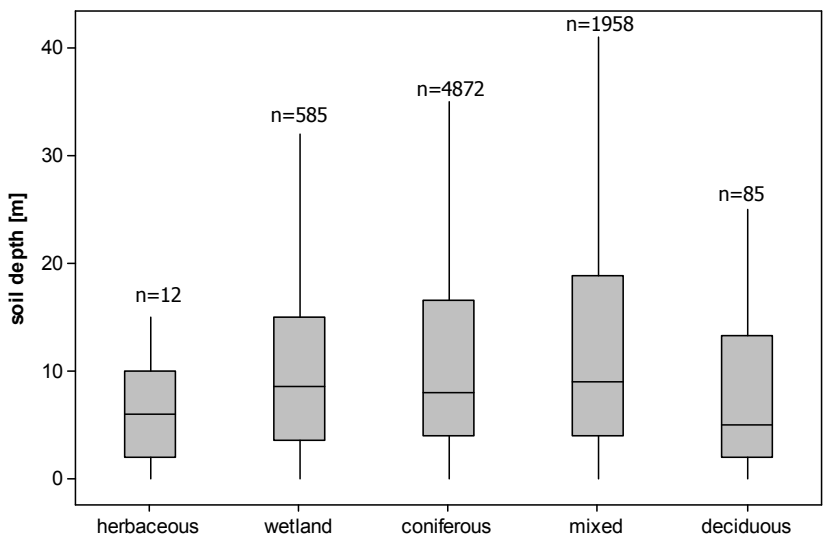

Fig. 3. Distribution of the soil sample points for coniferous, mixed and deciduous forest, herbaceous and wetland land cover classes; the gray box represents the interquartile range, whereas the top indicates the third quartile and the bottom the first quartile; the line within the box gives the median value.

\subsection{Data sources}

Maps from the EU Joint Research Center (JRC) were used to estimate vegetation cover in the catchments. The vegetation raster maps has a spatial resolution of $150 \mathrm{~m}$. Drainage area boundaries were obtained from the Swedish Meteorological and Hydrological Institute (SMHI). Point estimates of soil depth distributed throughout the catchments were obtained from the Geological Survey of Sweden (SGU). River chemistry data from monthly measurements since 1970, was obtained from the Swedish University of Agricultural Sciences databank (SLU, www.ma.slu.se) and from seasonal field sampling carried out in 1999-2001 for sub-catchments of the rivers Kalixälven and Luleälven (Humborg et al., 2002, 2004). Water discharge data from Humborg et al. (2004) where a semi-distributed conceptual runoff model, the HBV model (Lindström et al., 1997) had been used to estimate runoff.

\subsection{Land cover}

Distributions of the land cover classes for each catchment were calculated using ArcMap 9.1 (ESRI). The land cover class "wetland" contains both permanent wetland areas as well as regularly flooded areas; the land cover class "forest" has three sub-classes, "deciduous", "coniferous" and "mixed". "Herbaceous areas" include alpine pasture. Additionally, distributions of the land classes "cultivated", "artificial", "bare areas", "ice" and "water" were calculated.

\subsection{Soil depth of the river catchments}

Throughout this paper soil and soil-depth refers to everything overlying bedrock, i.e. both the developed soil horizons as well as the underlying unconsolidated deposits. For this large-scale attempt to calculate average soil depth of the various river catchments we used 7512 sample points from SGU's well database. $80 \%$ of the points came from wells drilled down to the bedrock, $16.5 \%$ ending in soil and 3.5\% with an uncertain ending. Thus, about $20 \%$ of the data can be estimated as minimum depth. By overlaying these sample points on the land cover data, the well sample points could be correlated to individual land cover classes and from this correlation a median soil depth for the land cover classes could be calculated (Fig. 3). The number of measured soil depths in the different land covers classes varied. Most sample points were found in the "coniferous forest" class $(n=4872)$, followed by the "mixed forest" class $(n=1958)$, the "wetland" class $(n=585)$, "deciduous forest" class $(n=85)$ and only 12 in the "herbaceous class". Median soil depth values ranged from $5 \mathrm{~m}$ (deciduous forest) to $9 \mathrm{~m}$ (mixed forest) (Fig. 3). Soil depth of the land cover classes bare, water and ice were assumed to be zero.

The areas of the individual land classes were calculated for each investigated catchment. The median soil depth for each land class was then used to calculate soil volumes for each catchment area. Based on the total soil volume from all land classes an average soil depth was calculated for each of the investigated catchments.

\subsection{Digital Elevation Model, DEM}

To investigate the relationship between topography, vegetation and soil depths in the headwater catchments we used a digital elevation model (DEM) with a $250 \mathrm{~m}$ spatial resolution to create 3-D maps of vegetation and soils. These were created by draping the vegetation map and soil map onto the DEM. Because the number of available soil sample points in themselves was insufficient to produce a digital grid without gross extrapolation, especially at high altitudes where fewer wells are drilled, we first created an additional set of points based on the median soil depths of the five vegetation land cover classes (Fig. 3) and zero for the classes bare, water and ice. To these land cover class based points we added all available SGU data points, 7512 on soil depth from the well database and 54835 points marking rock outcrops. In order to give precedence to the measured SGU data, all land cover class based points located within a buffer area with a $500 \mathrm{~m}$ radius from a SGU sample point were removed. A gridding using both data sets (measured SGU data points and derived data from land cover classes (Fig. 3) was then executed. The resulting digital grid with a $250 \mathrm{~m}$ resolution was opened in the 3-D visualization software Fledermaus ${ }^{\mathrm{TM}}$ and draped over the digital elevation model. Additional GIS systems used in this study was Global Mapper ${ }^{\mathrm{TM}}$ and Generic Mapping Tools. 


\subsection{Landscape element losses}

The landscape in the regulated river Luleälven has been affected in three distinctive ways. Some areas have been inundated, other areas have been bypassed due to tunnels rerouting the water, and finally some areas have been affected due to the alterations of the hydrological cycles and flow patterns thus affecting the riparian (Jansson et al., 2000) and hyporheic zones (White, 1993). The first two changes have been quantified in this study, whereas the third, i.e. qualitative changes in vegetation types along the main river courses have not been estimated.

The inundated areas by the Akka reservoir have been estimated by Humborg et al. (2002) based on general survey maps dated 1889. Unfortunately, this detailed information was not available for the entire Porjus catchment. For the areas inundated between the Suorva and Porjus Dams, i.e., along the Stora Lulevatten as well as the Satisjaure reservoir we assumed similar areas inundated as for the Akka reservoir, both in terms of total area and land cover class losses. This appears justified since the area of the Akka reservoir is about the same as the aggregated lake areas of the Stora Lulevatten and the Satisjaure. Predamming vegetation conditions of the inundated areas by the reservoirs Akka, Stora Lulevatten and the Satisjaure is described as mostly deciduous forest along a meandering riparian zone with areas of wetlands with sedges and peat and annually flooded areas (Curry-Lindahl, 1968). For the dammed Sitas catchment we made a conservative estimate of the inundated area to be $25 \%$ of the present water covered area. In the mountainous Sitas catchment land cover close to the waters is predominantly herbaceous with grass and sedge.

A tunnel reroutes the water from the Sitas reservoir straight into the Akka reservoir catchment, thus bypassing and affecting the entire Teusajaure catchment. The bypassed area was calculated using the catchment boundaries.

\subsection{Scale and resolution}

When using spatially distributed data, scale, classification and generalization always is an issue, especially affecting features and areas with an extent smaller than the used resolution. In this study, landscape features such as small mires, bogs and tributaries may have been overlooked due to their relative small size. However, our resolution covers all first order streams (Strahler, 1957) that were defined by CCM2 using a $100 \mathrm{~m}$ DEM (Vogt et al., 2007). The effect of eliminating small landscape elements such as mosaic occurrences of, for example, bare rock or mires in a deciduous forest would be that the entire area would be classified as deciduous forest and this would constitute the dominating landscape form. Therefore the specific role of mosaic river elements for river loading can not be addressed in this study. However, a fine resolution is more critical when focusing on detailed processes such as connectivity between land and stream in riparian zones where small tributaries will be lost in coarse resolution maps and also, the amount of near-stream area as a fraction of watershed area will increase (Baker, 2006). In this study, we looked at large scale differences in vegetation cover and types and their proximity to the main river channels that has been drained. Undoubtedly, land cover data with a finer resolution would have located greater amounts of small patches of vegetation types. With the used scale on the DEM and the land cover classification, the boundaries of the vital vegetation types will, admittedly, be fuzzier than with a finer scale that would produce more focused "hot-spot" areas. However, these pin pointed areas would still, most likely, be located within the areas located using the coarser scale. Finally, the used information on river chemistry was only provided on a coarser scale than the DEM. The smallest scale of available river chemistry data is the junction of first and second order streams defined by the CCM2 DEM and, thus, disregards the contribution of individual landscape patches.

\section{Results}

\subsection{Average soil depth, vegetation cover and annual spe- cific discharge of the catchments}

The large river catchments showed average soil depths ranging from $6.0-6.6 \mathrm{~m}$ for the heavily regulated catchment of Luleälven and Skellefteälven, over $7.2 \mathrm{~m}$ for Umeälven, Piteälven, and Torneälven, to 7.6-8.1 m for the unperturbed catchments of the Kalixälven and Råneälven. Highest annual specific discharge of these large catchments showed the Luleälven with $698 \mathrm{~mm}$ followed by Kalixälven $(572 \mathrm{~mm})$, Umeälven $(571 \mathrm{~mm})$, Piteälven $(529 \mathrm{~mm})$, Skellefteälven $(510 \mathrm{~mm})$, Råneälven $(352 \mathrm{~mm})$ and the lowest annual specific discharge showed the Torneälven $(348 \mathrm{~mm})$. More than $75 \%$ of the areas in the major catchments were covered with vegetation land cover classes, i.e., forests, wetlands and herbaceous areas.

Within the group of sub-catchments the herbaceous cover was rather evenly distributed around 30\% with the exceptions of the two wetlands dominated catchments of Muddusätno and Sjauniaätno that hardly had any herbaceous areas. Thus, the sub-catchments varied mostly in their aggregated forest and wetland cover. The sub-catchments of Muddusätno and Sjauniaätno showed the thickest average soil depth of 8.2 and $8.0 \mathrm{~m}$, respectively. The sub-catchment of Killingi with an aggregated forest, wetland and herbaceous cover of $82.7 \%$ showed an average soil cover of $5.9 \mathrm{~m}$. The mountainous headwater sub-catchments all showed in general a thinner average soil layer that decreased with altitude. In the Kalixälven headwaters the sub-catchment of Tarfalajåkka showed an average soil depth of $1.7 \mathrm{~m}$, followed by the downstream catchments of Ladtjojåkkal and 2 with a soil depth of 3.4 and $3.9 \mathrm{~m}$, respectively. Annual 

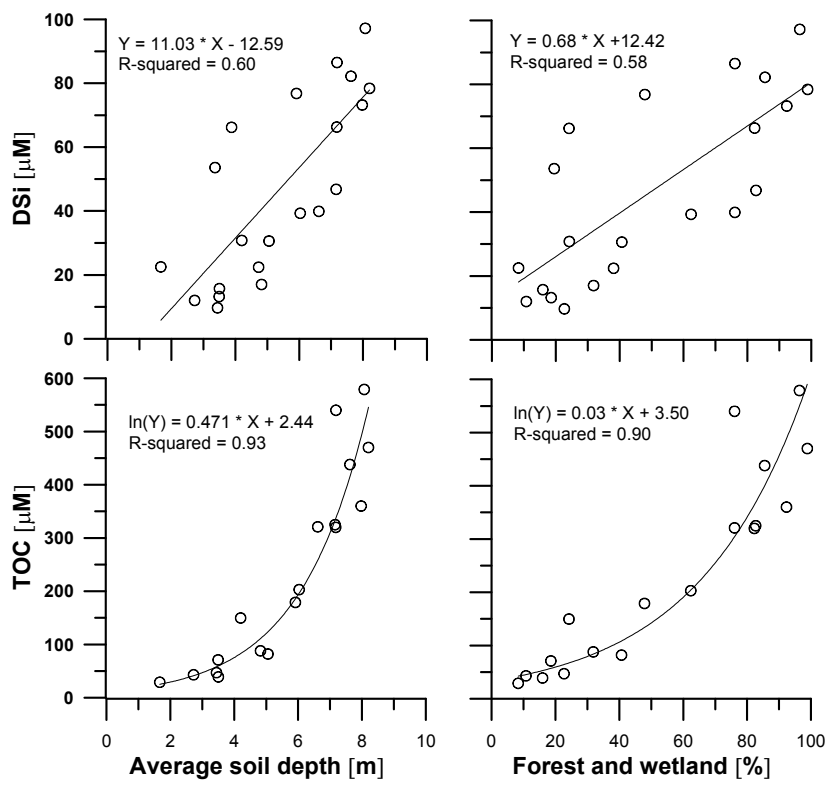

Fig. 4. In stream TOC and DSi discharge-weighted mean concentrations plotted against vegetated area percentages and soil depths, respectively. Vegetated area includes forest (deciduous, mixed and coniferous), wetland and herbaceous.

specific discharge for these three catchments was 570, 592, and $567 \mathrm{~mm}$ and their aggregated forest and wetland percentage was rather low $(8.3,19.5$ and $24.2 \%)$ and consisted mostly of Betula and Salix spp.

In the headwaters of the Luleälven the unperturbed catchments of Sårkkajåkka, Vuojatätno and Upmas showed soil depths of $3.4,3.5$ and $4.8 \mathrm{~m}$, respectively. Annual specific discharge $(1006-1206 \mathrm{~mm})$ was about double that of the headwaters of the Kalixälven, whereas the forest and wetland cover was similarly low (15.9-35.8\%). An exception is the unperturbed catchment of Valtajåkka that is located in a rain shadow within the Luleälven headwaters and showed $469 \mathrm{~mm}$ annual specific discharge. This subcatchment is covered by $40.7 \%$ forests and wetlands and showed an average soil depth of $5.1 \mathrm{~m}$. The regulated catchment of Sitas showed a low percentage aggregated forest and wetland $(10.7 \%)$ and the highest annual specific discharge of all the investigated catchments, $1288 \mathrm{~mm}$; the average soil depth was $2.7 \mathrm{~m}$. The bypassed Teusajaure catchment showed an aggregated forest, wetland and herbaceous cover of $61.9 \%$ and an average soil depth of $4.5 \mathrm{~m}$. The Akka catchment holding the large Akka reservoir showed an average soil depth of $3.5 \mathrm{~m}$, an annual specific discharge of $864 \mathrm{~mm}$ and an aggregated forest and wetland cover of $18.5 \%$. Finally, the entire Porjus catchment showed an average soil depth of $4.7 \mathrm{~m}$, an annual specific discharge of $829 \mathrm{~mm}$ and an aggregated forest and wetland cover of $38.1 \%$.

\subsection{Land cover and soil depth vs. river chemistry}

First, we tested the relationships between the individual land cover classes and TOC and DSi, respectively. Whereas "wetland" cover and "forest" cover explained the variability in DSi concentrations similarly ( $\mathrm{R}$ squared values of 0.39 and 0.41 , respectively), the "forest" cover had a higher explanatory power to describe the variability in TOC concentrations (R squared value of 0.73 ) compared to "wetland" cover (R squared value of 0.41). In contrast, the land cover class "herbaceous" was slightly negatively correlated to both DSi and TOC concentrations found in the 22 catchments.

In the next step, we grouped the two vegetation types positively correlated to the river chemistry variables as an explanatory variable for TOC and DSi. Vegetative cover (the sum of forest and wetland) plotted against TOC and DSi showed rather good relationships, either log-linear (TOC) or linear (DSi), with R-squared values of 0.90 and 0.58 , respectively. Similarly strong relationships were found when average soil depth is plotted against TOC and DSi (R-squared 0.93 and 0.60 , respectively) (Fig. 4). Note that the average soil depth of a catchment has been derived from the median soil depth of the land classes, forests (deciduous, coniferous and mixed), wetlands and herbaceous, but also from the spatial extensions of "bare areas", "ice" and "water". Thus, the variables vegetative cover and average soil depth are interlinked, but are not necessarily the same. However, high DSi and TOC concentrations were found in wetland-dominated catchments such as Muddusätno and Sjauniaätno as well as in the large river catchments of Torneälven, Kalixälven and Råneälven with the highest percentage of forest, wetlands and herbaceous areas within the group of major catchments.

The general trend of increasing TOC and DSi concentrations with increasing cover of forests, wetlands and herbaceous were also found for the unperturbed catchments of the Kalixälven and Luleälven. DSi concentrations increased downstream from $23 \mu \mathrm{M}$ in the Tarfalajåkka over 54-66 $\mu \mathrm{M}$ in the Ladtjojåkka 1 and 2 to the Killinge catchment showing $77 \mu \mathrm{M}$. In the unperturbed headwater catchments of the Luleälven, lowest DSi concentrations were found in the Sårkajåkka $(10 \mu \mathrm{M})$ and Vuojatätno $(15 \mu \mathrm{M})$ followed by the Upmas $(17 \mu \mathrm{M})$ and Valtajåkka $(31 \mu \mathrm{M})$ with higher cover of forest, wetlands and herbaceous areas (Table 1).

\subsection{Landscape characteristics as derived from a draped DEM}

The elevation model draped with land cover and soil depth visualizes the spatial distribution of the vital landscape elements for river chemistry such as forests and flooded wetlands as well the thicker soil layers (Figs. 5, 6). Without the 3-D perspective the clear relationship soil depth and topography cannot be seen. Most of mountainous headwater areas have only a limited amount of wetlands and forests in the catchments and these vital landscape elements are mostly 
Table 2. Inundated or bypassed areas in the Porjus catchment. Total area, deciduous forest, mixed forest, coniferous forest, wetland, and herbaceous area in hectare for the affected sub-catchments. Also, hydrological status is noted. Note that the areas are not aggregated except for the total Porjus.

\begin{tabular}{|c|c|c|c|c|c|c|c|}
\hline Catchment & $\begin{array}{l}\text { Area in ha lost } \\
\text { due to regulation }\end{array}$ & $\begin{array}{l}\text { Deciduous forest area lost } \\
\text { due to regulation (ha) }\end{array}$ & $\begin{array}{l}\text { Mixed forest area lost } \\
\text { due to regulation (ha) }\end{array}$ & $\begin{array}{c}\text { Coniferous forest area lost } \\
\text { due to regulation (ha) }\end{array}$ & $\begin{array}{c}\text { Wetland area lost } \\
\text { due to regulation (ha) }\end{array}$ & $\begin{array}{l}\text { Herbaceous area lost } \\
\text { due to regulation (ha) }\end{array}$ & $\begin{array}{l}\text { Hydrological } \\
\text { status }\end{array}$ \\
\hline Sitas & 2816 & 0 & 0 & 0 & 0 & 2816 & Dammed \\
\hline Akka & 12700 & 10000 & 0 & 0 & 2700 & 0 & Dammed \\
\hline Teusajaure & 64960 & 3640 & 4511 & 6453 & 2130 & 23492 & Bypassed \\
\hline Stora Lulevatten & 12700 & 10000 & 0 & 0 & 2700 & 0 & Dammed \\
\hline Total Porjus & 93176 & 23640 & 4511 & 6453 & 7530 & 26308 & Dammed \\
\hline
\end{tabular}

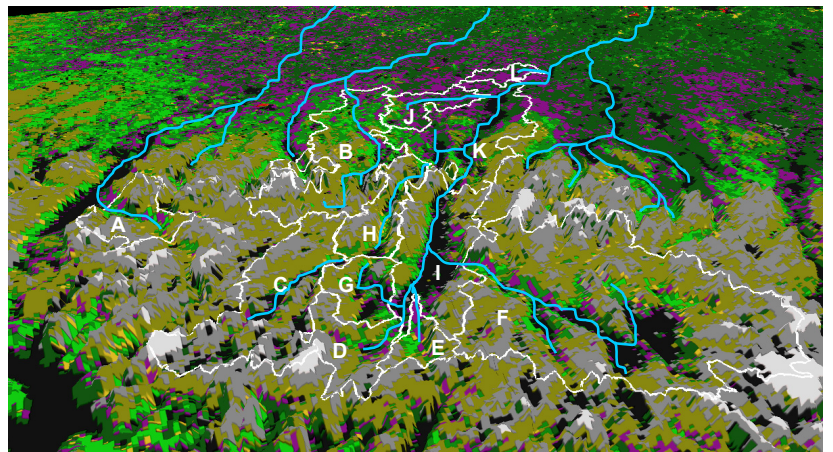

Fig. 5. Land classes draped over a DEM. View over the River Luleälven headwaters towards southeast with the rivers Kalixälven and Torneälven on the left. Note, that deciduous forest and wetland classes in high altitude areas are located along the main river corridors (marked in blue). Land cover colors as in the legend in Fig. 2. A=Abiskojåkka, B=Killingi with Tarfalajåkka and Ladtjojåkka 1 and 2 to the left, partly obscured by the Mount Kebnekaise, $\mathrm{C}=$ Sitas, $\mathrm{D}=$ Sårkkajåkka, $\mathrm{E}=$ Valtajåkka, $\mathrm{F}=$ Vuojatätno, $\mathrm{G}=\mathrm{Upmas}, \mathrm{H}=$ Teusajaure, $\mathrm{I}=\mathrm{Akka}$ res., $\mathrm{J}=$ Sjauniaätno, $\mathrm{K}=$ Porjus, $\mathrm{L}=$ Muddusätno.

located along the fluvial corridors in valley floors and connecting flatter areas. Here, alluvial deposits have been accumulated forming hot spots of thicker soil layers (Fig. 6) giving preconditions for higher plant growth (Fig. 5). Note, that these areas bordering the streams and rivers are vegetated mainly by deciduous forest and wetlands whereas other land class types, such as herbaceous areas and coniferous forest, are more randomly distributed in the headwater catchments and also on higher locations (Fig. 5). Intensive areas of deciduous forest and wetlands are visible in Fig. 5 especially along the river corridors of the Abiskojåkka, Valtajåkka, but also along the entire Akka reservoir.

\subsection{Landscape element losses in the headwaters of the river Luleälven}

In the mountainous Sitas catchment located above $600 \mathrm{~m}$ a.s.l., we estimated that some 2816 hectares of herbaceous land have been inundated due to the creation of

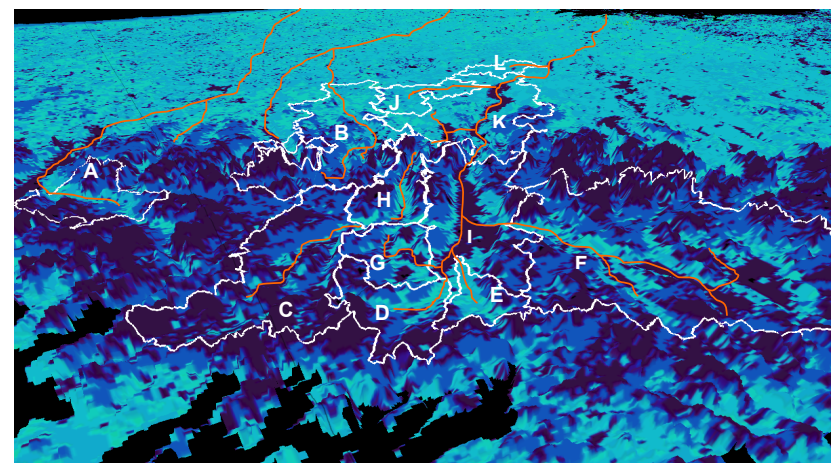

Fig. 6. Soil depth draped over a DEM. View over the River Luleälven headwaters towards southeast with the rivers Kalixälven and Torneälven on the left. Brighter colors indicate thicker soil layer. Water is classified as zero soil depth. Main river corridors marked in red. $\mathrm{A}=\mathrm{Abiskojåkka,} \mathrm{B}=$ Killingi with Tarfalajåkka and Ladtjojåkka 1 and 2 to the left, partly obscured by the Mount Kebnekaise, $\mathrm{C}=$ Sitas, $\mathrm{D}=$ Sårkkajåkka, $\mathrm{E}=$ Valtajåkka, $\mathrm{F}=$ Vuojatätno, $\mathrm{G}=$ Upmas, $\mathrm{H}=$ Teusajaure, $\mathrm{I}=\mathrm{Akka}$ res., $\mathrm{J}=$ Sjauniaätno, $\mathrm{K}=$ Porjus, $\mathrm{L}=$ Muddusätno.

the reservoir (Table 2). Within the Akka catchment about 10000 hectares of deciduous forest and 2700 hectares of wetlands have been inundated by the Akka reservoir at (453 $\mathrm{m}$ a.s.1.). About the same amount have been inundated by the Satis reservoir ( $457 \mathrm{~m}$ a.s.l.) and the Stora Lulevattnet ( $372 \mathrm{~m}$ a.s.1.) (see Methods section). In Teusajaure catchment 3640 hectares of deciduous forest, 4511 hectares of mixed forest, 6453 hectares of coniferous forest, 2130 hectares of wetland and 23492 hectares of herbaceous land have been bypassed by a tunnel from the Sitas reservoir to the Akka reservoir thus disrupting the former contact between the vegetated soils and the flowing water.

Adding these lost areas for the entire Porjus catchments shows that $3 \%$ of the pre-damming area is inundated due to river regulation. When the bypassed catchment of Teusajaure, downstream of the Lake Sitas reservoir, is included the affected area becomes $9.4 \%$. The soil volume of these inundated and bypassed areas comprises $9.5 \%$ of the total estimated soil volume in the Porjus catchment. With an assumed total area of 28216 ha inundated by regulation in the Porjus 
catchment we distributed the inundated areas in a proportion of 20000 ha of deciduous forest, 5400 ha of wetlands and 2816 ha herbaceous areas. In other words, some $11 \%$ of the area covered by forests, wetlands and herbaceous areas and $37 \%$ of the deciduous forest in the Porjus catchment prior to damming is now inundated or bypassed. Thus, damming affected mainly deciduous forest and wetlands forming the riparian zone found along the river corridors.

\section{Discussion}

This study indicates that damming may lead to a preferential loss of vital land class elements located along the river valleys that form a riparian zone covered by deciduous forests and wetlands. The study also corroborates recent findings that weathering regimes and vegetation cover in river catchments are intimately linked (Conley, 2002; Derry et al., 2005), suggesting a prominent role of the biosphere for weathering reactions in addition to the previously examined role of physicochemical mineral-water reactions (Garrels and Mackenzie, 1971; Stumm and Morgan, 1996). Today, some $30 \%$ of the surface waters entering the oceans have passed through a reservoir (Milliman, 1997; Vörösmarty and Sahagian, 2000). However, these reservoirs cover only a minor fraction of the total catchment area and the general perception has been that mainly in-lake processes such as phytoplankton blooms (Friedl et al., 2004) and sedimentation of total suspended sediments (Syvitski, 2003; Syvitski et al., 2005) are the major processes changing the river chemistry in these catchments. Perturbation in headwater areas, as shown in this study, can be more significant than hydrological alterations downstream, since these areas are characterized by high annual specific discharge and only a critical mass of hot spots, i.e., a thin soil and vegetation cover. Our DEM model demonstrated that these are the locations in the headwaters where significant soil layers have been formed as alluvial deposits and our estimate for the Swedish river Luleälven shows that $10 \%$ of these soils, $11 \%$ of forest, wetland and herbaceous areas, and about $37 \%$ of the critical deciduous forest forming the riparian zone are lost due to water regulation. High concentrations of TOC and DSi occurred only in headwater catchments with an average soil depth $>5 \mathrm{~m}$ and a forest and wetland coverage $>40 \%$ of the catchment area.

\subsection{The riparian zone - a hot spot for DSi river loading in arctic headwaters?}

The average soil cover of river catchments appears vital for the biogeochemical processes since this affects the flow paths of water and thereby is an important factor for the soil/water contact time. Studies by McGuire et al. (2005) has related water residence time (using topographic index) to river chemistry and shown that the increased concentrations of weathering products are correlated with an increase in res- idence time. Changes in soil cover, especially in headwater areas are therefore crucial for the river network and water flow path length and, thus, for the residence time, resulting in shorter soil/water contact and a decrease in weathering products. The importance of soil cover is in this study evident from the fact that average soil depth explains 58 and 93\% of the observed variability in DSi and TOC concentrations. In our attempt to estimate the average soil depth of a given catchment we used sample points from the SGU well database together with information on areas not covered with soils, i.e., water, ice and outcrops. Most of the well data cover soil depth down to the bedrock; however, the average soil depth estimate is biased in the sense that the well data are not randomly collected. Wells are placed at locations where people live, i.e., most data are from the area between the coast and the hill slopes; the mountainous areas are under represented. This means that we have fairly good coverage of data for the larger catchments by means of well data at the lowlands and data on outcrops in the headwaters, both with good coverage. On the other hand, real observed soil depth in the headwaters are few and we assumed an average soil depth of a given land cover class derived with most measurements from the lowlands. Therefore, we may regard the estimates of soil depth in headwater as an overestimate, since these areas are much more exposed to erosion and a thinner soil cover should be expected with altitude in general. However, using these measured soil depths should be seen as a first attempt to estimate soil volumes on a large scale and also to visualize the spatial distribution within a catchment. Thus, this study shows for the first time the limited spatial and vertical extension of soils in Swedish headwaters making these areas susceptible for hydrological alterations.

We estimate a total loss of 28216 ha due to inundation and can be compared to independent estimates from the Swedish Meteorological and Hydrological Survey that estimated a total of 26200 ha as inundated by the four major reservoirs (Carlsson and Sanner, 1994). The major part of these inundated areas was deciduous forests that formed the riparian zone. Figure 5 shows nicely that deciduous forest and wetlands are mainly found along the fluvial corridors. These GIS maps and the draped DEM only indicate their spatial aggregations, a detailed vegetation structure of the riparian zones in these areas can be found in Curry-Lindahl (1968); Nilsson (1983); Nilsson and Berggren (2000); Jansson (2002). The riparian zone in the headwaters of these subarctic rivers often forms a mixture from birch (Betula spp.) and various willow (Salix spp.) species followed closer to the water by grasses, sedges and equisetum. These vegetation types are adapted to regularly flooding and thus have a character of a wetland. Moreover, grasses and sedges are known to contain significant amount of amorphous silica in their biomass (Saccone et al., 2007). In a recent study, Struyf and Conley (2009) have shown that especially these arctic wetlands are impressive storages of amorphous silica (ASi) that are either diatom frustules or phytoliths (Piperno, 1988). Initial analyses show 
that subarctic wetlands in Northern Sweden contain 1-5\% of ASi by weight percent, which is an order of magnitude above the amount stored in temperate wetlands and confirm the capacity of subarctic wetlands to accumulate large amounts of ASi. We cannot yet quantify the exact contributions of these ASi storages along the riparian zones and wetlands to the overall DSi fluxes in these headwater catchments; however, a reduction with some $40 \%$ of this land cover class appears rather drastic.

Moreover, the riparian zone formed by deciduous forest and wetlands was further destroyed by the unnatural flow patterns within the entire river catchment. Within the major reservoir the riparian zone is further lost by the drastic water level variations of up to $34 \mathrm{~m}$ in the Akka reservoir, leaving behind only bare rocks and gravel. Downstream of major dams, water level fluctuations are often diminished compared to those of unregulated rivers due to the more evened out flow generated by the hydroelectric power stations, and also owing to storage for flood control (Jansson et al., 2000). This means that the riparian zone downstream of major dams is much reduced, and the exchange processes in the hyporheic zone (White, 1993), where mixing between groundwater and surface water occurs, are also diminished. It has been shown that continuous saturation and rapid flushing of the sediment due to hyporheic exchange facilitates Si weathering and is responsible for significant $\mathrm{Si}$ supply to small streams in arctic areas (Gooseff et al., 2002; Maurice et al., 2002).

\subsection{DEM indicating flow path and soil contact times of waters instrumental for river chemistry}

The DEM gives a first indication of water residence time in the soil within the various land cover classes of the headwater catchments. The surface waters and ground waters run down the steep slopes that are covered with mainly herbaceous vegetation and some occurrences of coniferous forests rather quickly compared to the flatter river corridors where the riparian zone have been established and the water infiltrates the alluvial sediments. Thus, the soil/water contact time will obviously increase downstream. A long soil/water contact time increases also the potential for a build up of a ASi pool in the soils that is further enhanced by regular flooding events that in turn lead to an enhanced deposition of suspended soils, sediment associated phytoliths and diatoms (Struyf and Conley, 2009). In other words, these authors suggest that the wetland rich areas, such as the riparian zone, of arctic and boreal river systems has evolved to a massive $\mathrm{Si}$ storage since the last glaciation and act now as a significant source for DSi in these river systems.

\section{Conclusions}

The hypothesis we wanted to test in this study was whether individual land classes within a river catchment contribute equally to river loading with dissolved constituents and whether some land classes act as "hot spots" to river loading and if so, are these land classes especially affected by hydrological alterations. Contact time between soil and water is a fundamental variable for controlling river chemistry and can be related to the steepness or topographic index (McGuire et al., 2005) of a catchment area, and derived from DEMs. Topographic complexity is also important in understanding processes in soils in boreal catchments of northern Sweden (Seibert et al., 2007). Our study suggests that high annual specific discharge and the steepness of headwaters jointly determine hot spots of the river loading of dissolved constituents. These hot spots, the wetlands and deciduous forests forming the riparian zone along the river corridors, are where essentially all waters from the upper mountainous areas are channeled through and the soil/water contact time increases. Although we have only indirect evidence as of yet, a $40 \%$ loss of the riparian zones might be instrumental in explaining the observed lower fluxes of dissolved constituents from the regulated river catchments. However, future hydrological studies will need to better address the flow paths and water residence time through various land cover classes and soil types that may act as hot spots, since the response will depend critically on their configuration in the landscape.

Edited by: C. De Michele

\section{References}

Alexandersson, H., Karlström, C., and Larsson-McCann, S.: Temperaturen och nederbörden i Sverige 1961-90, Rep. Swedish Meteorological and Hydrological Institute M, 81, Norrköping, 1991.

Baker, M. E., Weller, D. E., and Jordan, T. E.: Effects of stream map resolution on measures of riparian buffer distribution and nutrient retention potential, Landscape Ecology, 22, 973-992, 2007.

Brydsten, L., Jansson, M., Anderson, T., and Nilsson, Å.: Element transport in regulated and non-regulated rivers in northern Sweden, Regulated rivers, Research Manage., 5, 167-176, 1990.

Carlsson, B. and Sanner, H.: Influence of river regulation on runoff to the Gulf of Bothnia - The Gulf of Bothnia Year 1991. Report No. RH No.9, Swedish Meteorological and Hydrological Institute, Norrköping, Sweden, 1994.

Conley, D. J.: Terrestrial ecosystems and the global biogeochemical silica cycle, Global Biogeochem. Cycles, 16(4), 1121, doi:10.1029/2002GB001894, 2002.

Curry-Lindahl, K.: Sarek, Stora Sjöfallet, Padjelanta: three national parks in Swedish Lapland. Rabén \& Sjögren, Stockholm, 1968.

Derry, L. A., Kurtz, A. C., Ziegler, K., and Chadwick, O. A.: Biological control of terrestrial silica cycling and export fluxes to watersheds, Nature, 433, 728-731, 2005.

Dugdale, R. C. and Wilkerson, F. P.: Silicate regulation of new production in the equatorial Pacific upwelling, Nature, 391, 270273, 1998.

Friedl, G., Teodoru, C., and Wehrli, B.: Is the Iron Gate I reservoir on the Danube River a sink for dissolved silica?, Biogeochem- 
istry, 68, 21-32, 2004.

Friedl, G. and Wuest, A.: Disrupting biogeochemical cycles - Consequences of damming, Aquat. Sci., 64, 55-65, 2002.

Garnier, J., Leporcq, B., Sanchez, N., and Philippon, X.: Biogeochemical mass-balances $(\mathrm{C}, \mathrm{N}, \mathrm{P}, \mathrm{Si})$ in three large reservoirs of the Seine Basin (France), Biogeochemistry, 47, 119-146, 1999.

Garrels, R. M. and Mackenzie, F. T.: Evolution of Sedimentary Rocks, Norton \& Company, New York, 1971.

Gooseff, M. N., McKnight, D. M., Lyons, W. B., and Blum, A. E.: Weathering reactions and hyporheic exchange controls on stream water chemistry in a glacial meltwater stream in the McMurdo Dry Valleys, Water Resour. Res., 38(12), 1279, doi:10.1029/2001WR000834, 2002.

Humborg, C., Blomqvist, S., Avsan, E., Bergensund, Y., Smedberg, E., Brink, J., and Mörth, C.-M.: Hydrological alterations with river damming in northern Sweden: Implications for weathering and river biogeochemistry, Global Biogeochem. Cycles, 16(3), 1039, doi:10.1029/2000GB001369, 2002.

Humborg, C., Ittekkot, V., Cociasu, A., and von Bodungen, B.: Effect of Danube River dam on Black Sea biogeochemistry and ecosystem structure, Nature, 386, 385-388, 1997.

Humborg, C., Smedberg, E., Blomqvist, S., Mörth, C.-M., Brink, J., Rahm, L., Danielsson, A., and Sahlberg, J.: Nutrient variations in boreal and subarctic Swedish Rivers: Landscape control of land-sea fluxes, Limnol. Oceanogr., 49, 1871-1883, 2004.

Ittekkot, V., Humborg, C., and Schafer, P.: Hydrological alterations and marine biogeochemistry: A silicate issue?, Bioscience, 50, 776-782, 2000.

Jansson, R.: Floran återhämtar sig inte längs utbyggda älvar [Reduced diversity in riparian zones along regulated rivers.], Svensk botanisk tidskrift, 96, 154-160, 2002.

Jansson, R., Nilsson, C., Dynesius, M., and Andersson, E.: Effects of river regulation on river-margin vegetation: A comparison of eight boreal rivers, Ecol. Appl., 10, 203-224, 2000.

Laudon, H., Sjöblom, V., Buffam, I., Seibert, J., and Mörth, C.M.: The role of catchment scale and landscape characteristics for runoff generation of boreal streams, J. Hydrol., 344, 198209, 2007.

Lindström, G., Johansson, B., Persson, M., Gardelin, M., and Bergström, S.: Development and test of the distributed HBV-96 hydrlogical model, J. Hydrol., 201, 272-288, 1997.

Maurice, P. A., McKnight, D. M., Leff, L., Fulghum, J. E., and Gooseff, M.: Direct observations of aluminosilicate weathering in the hyporheic zone of an Antarctic Dry Valley stream, Geochim. Cosmochim. Ac., 66, 1335-1347, 2002.

McGuire, K. J., McDonnell, J. J., Weiler, M., Kendall, C., McGlynn, B. L., Welker, J. M., and Seibert, J.: The role of topography on catchment-scale water residence time, Water Resour. Res., 41(5), W05002, doi:10.1029/2004WR003657, 2005.

Meybeck, M.: Riverine quality at the Anthropocene: Propositions for global space and time analysis, illustrated by the Seine River, Aquat. Sci., 64, 376-393, 2002.

Milliman, J. D.: Oceanography - Blessed dams or damned dams?, Nature, 386, 325-326, 1997.
Millot, R., Gaillardet, J., Dupre, B., and Allegre, C. J.: Northern latitude chemical weathering rates: Clues from the Mackenzie River Basin, Canada, Geochim. Cosmochim. Ac., 67, 13051329, 2003.

Moulton, K. L., West, J., and Berner, R. A.: Solute flux and mineral mass balance approaches to the quantification of plant effects on silicate weathering, Am. J. Sci., 300, 539-570, 2000.

Nilsson, C.: Frequency-Distributions of Vascular Plants in the Geolittoral Vegetation Along two Rivers in Northern Sweden, J. Biogeogr., 10, 351-369, 1983.

Nilsson, C. and Berggren, K.: Alterations of riparian ecosystems caused by river regulation, Bioscience, 50, 783-792, 2000.

Piperno, D.: Phytolith analysis - an archeological and geological perspective, Academic Press, San Diego, 1988.

Saccone, L., Conley, D. J., Koning, E., Sauer, D., Sommer, M., Kaczorek, D., Blecker, S. W., and Kelly, E. F.: Assessing the extraction and quantification of amorphous silica in soils of forest and grassland ecosystems, Eur. J. Soil Sci., 58, 1446-1459, 2007.

Seibert, J., Stendahl, J., and Sørensen, R.: Topographical influences on soil properties in boreal forests, Geoderma, 141, 139-148, 2007.

Sferratore, A., Billen G., Garnier, J., Smedberg, E., Humborg, C., and Rahm, L.: Modelling nutrient fluxes from sub-arctic basins: Comparison of pristine vs. dammed rivers, J., Marine Syst., 73(3-4), 236-249, 2008.

Strahler, A. H.: Quantitative analysis of watershed geomorphology, Geophysical Union Transactions, 38, 1290-1299, 1957.

Struyf, E. and Conley, D., J.: Silica: an essential nutrient in wetland biogeochemistry, Front. Ecol. Environ., 7(2), 88-94, 2009.

Stumm, W. and Morgan, J. J.: Aquatic Chemistry, John Wiley \& Sons, New York, 1996.

Syvitski, J. P. M.: Supply and flux of sediment along hydrological pathways: research for the 21 st century, Global Planet. Change, 39, 1-11, 2003.

Syvitski, J. P. M., Vorosmarty, C. J., Kettner, A. J., and Green, P.: Impact of humans on the flux of terrestrial sediment to the global coastal ocean, Science, 308, 376-380, 2005.

Turner, R. E. and Rabalais, N. N.: Coastal Eutrophication near the Mississippi River Delta, Nature, 368, 619-621, 1994.

Van Bennekom, J. and Salomons, W.: Pathways of nutrients and organic matter from land to ocean through rivers, in: River Inputs to Ocean Systems. UNEP, IOC, SCOR, edited by: Martin, J.-M., Burton, J. D., and Eisma, D., United Nations, New York, Rome, pp. 33-51, 1979.

White, D. S.: Perspectives on Defining and Delineating Hyporheic Zones, J. N. Am. Benthol. Soc., 12, 61-69, 1993.

Vogt, J. V., Soille, P., de Jager, A., Rimaviciute, E., Mehl, W., Haastrup, P., Paracchini, M. L., Dusart, J., Bódis, K., Foisneau, S., and Bamps, C.: Developing a pan-European Data Base of Drainage Networks and Catchment Boundaries from a 100 Metre DEM, Proceedings AGILE International Conference, May 2007.

Vörösmarty, C. J. and Sahagian, D.: Anthropogenic disturbance of the terrestrial water cycle, Bioscience, 50, 753-765, 2000. 